\title{
Research on the Impact of E-commerce to Logistics Economy: An Empirical Analysis based on Zhengzhou Airport Logistics
}

\author{
Lei Wang \\ School of Economics and Management, Zhongyuan University of Technology, \\ Zhengzhou 450007, China
}

\begin{abstract}
With the rapid development of e-commerce, customer demand for diversity and timeliness has also increased, in fact, B2C e-commerce business lead higher requirement for logistics service. At the same time, the aviation logistics has become a new growth point of China's logistics transportation development, airport logistics construction and development has become an important force to promote regional economy. In this paper, we make empirical analysis about the logistics performance evaluation of Zhengzhou airport, China. The result shows that reliability, economy, time, service flexibility and information are five key factors that will influence the logistics performance. On this basis, we put forward relevant policy suggestions.
\end{abstract}

Keywords: E-commerce; Logistics economy; Zhengzhou airport; Logistics distribution center

\section{Introduction}

In recent years, China's B2C e-commerce has been rapid development. According to a survey in 2014, according to a survey of the Chinese e-commerce market transactions reached $12.3 \mathrm{RMB}$, an increase of $21.3 \%$ compared with 2013. Among them, the $\mathrm{B} 2 \mathrm{C} \mathrm{e}-$ commerce accounted for $29.7 \%$, and the trend continues to increase [1]. B2C electronic commerce enterprise rapid development at the same time also to the logistics service put forward higher requirements. From the view of the characteristics of the purchase of electronic commerce, the customer is through the Internet to buy the required products, consumers have a wide range of distribution, and the purchase of products for personal consumption is limited, such a large range, high frequency of the purchase will improve the product distribution, the loss of the probability of damage. From the perspective of its development model, e-commerce logistics distribution network, the need to start the network, the customer's expectations of distribution service is a short time, high flexibility. The traditional logistics service under the B2C e-commerce is no longer only from the supplier to the buyer entity movement, but in the traditional logistics based on the pursuit of a short time, service flexibility, and high value-added services. Therefore, the quality of logistics distribution has become more and more important to the development of $\mathrm{B} 2 \mathrm{C}$ electronic commerce.

Despite the rapid development of $\mathrm{B} 2 \mathrm{C}$ electronic commerce, but the problems also need to be solved. E-commerce is growing up with the rapid development of the Internet, the customer online purchase products from the business to the product distribution mode, related to the online payment, network security and logistics distribution three aspects. And these three aspects of the problem in some extent hindered the development of electronic commerce. With the continuous development of network technology, network security and payment problems have been greatly improved, but the quality of logistics service of electronic commerce enterprise has not been improved obviously. From the view of the characteristics of electronic commerce purchase, the customer is through the Internet to buy the required products, consumers have a wide range of distribution, and for personal consumption, the number of its purchase of products, such a large range, high 
frequency of the purchase will increase the product distribution, loss of probability, so the logistics supplier in $\mathrm{B} 2 \mathrm{C}$ e-commerce. At present, the $\mathrm{B} 2 \mathrm{C}$ e-commerce enterprises in China use the third party logistics, some self built logistics, the difference of the model makes the distribution scope and ability are also different. In general, the quality of service provided by logistics providers in $\mathrm{B} 2 \mathrm{C}$ e-commerce in China is lower, especially in information service, which hinders the development of e-commerce enterprises. Therefore, to determine the service quality of B2C e-commerce logistics, find out the problems in its development, and to improve the service quality.

\section{Literature Review}

\subsection{E-commerce Logistics}

Logistics distribution is a bridge between e-commerce enterprises and consumers. From the point of view of enterprises, the core competitiveness of e-commerce enterprises is not limited to price competition, the logistics service is becoming more and more important, and the logistics distribution has a great influence on consumer's cognition and trust. Logistics industry is the earliest in the western developed countries, so they have a good logistics base and a more mature logistics theory, their research on the logistics needs of the main focus of the enterprise's demand forecast. Foreign scholars in the study of demand forecasting are mostly using the quantitative economic model, at the same time, they are also very important for the exploration of forecasting methods. Many developed countries in order to determine the size of the logistics market, often the logistics costs accounted for the proportion of GDP as a basis, in their view, the logistics cost is the best reflect the logistics needs of the comprehensive index, as well as some scholars to discuss the logistics volume and transport volume ratio, through the pre measurement of traffic volume to achieve the purpose of forecasting traffic flow.

Western scholars pay attention to the research of forecasting methods and models, and the invention and improvement of a variety of forecasting algorithms, and achieved a lot of results. Doina(2014) puts forward a view that the three methods of logistics demand forecasting are the cause and effect method, the time series method and the qualitative method respectively[2]. The regression method is a kind of causal method. The time series method is based on the historical data. The qualitative rule is based on the experience or the specific information, so as to predict the future. Lee(2011) proposed a regression model and time series model, and the freight volume of railway transportation as an example, using the two models were predicted[3].Samiee(2008) make contrast analysis of the exponential smoothing and ARIMA two forecasting methods, concluded that the index is smoother than the ARIMA operation is more simple, more accurate prediction[4].Mohamad(2012) analyze the aviation monthly data and proposed aviation data shows a nonlinear and suitable for the establishment of the grey model to forecast the demand for air[5].Liem(2013) proposed a combination forecasting method, which is based on the neural network model, and added the Gauss radial function network in the model[6].

The research shows that there are few studies on logistics demand in China. Only some scholars have studied the logistics demand forecasting methods based on the study of foreign countries. It has not formed a mature theory. This can be seen from several aspects: the domestic logistics system is not mature, lack of effective logistics statistics, so the logistics forecasting index selection is relatively simple, and the forecasting method is also various, and the research results are not authoritative. In this case, for the same logistics forecasting problem, because of the 
choice of indicators, the use of different forecasting methods, resulting in a great difference between the results, the prediction cannot be satisfactory.

\subsection{Logistics Distribution Center Performance}

According to the characteristics of the logistics distribution center of e-commerce enterprises, the scientific evaluation of the performance of the distribution center can be obtained from the electronic business enterprise logistics distribution center system is reasonable and can maximize customer satisfaction. With the continuous development of logistics and distribution system, the evaluation system and methods are required to meet the needs of the logistics distribution center.

Djelassi (2013) pointed out enterprise logistics performance evaluation is divided into three levels: first, the logistics enterprise internal resource utilization; two is the overall production efficiency of the logistics enterprise; three is the response time measurement [7]. They think that the performance evaluation system of the logistics distribution of e-commerce enterprises is mainly reflected in the accounting system, manufacturing plan and control system and other economic indicators and long-term strategic plan and so on. Zuo(2013) believes that the logistics evaluation index should include: sales growth, product utilization, cost, profit, resource price[8]. Shoki (2013) pointed out performance evaluation index of logistics enterprises has the productivity index and the assets index[9], he put forward that the logistics and distribution system should be built from two aspects: financial cost, productivity index, storage cost, distribution cost, transp ortation cost. For the first time, the logistics process of transportation, storage, and order management is measured, and the measurement of performance measurement needs to have five stages of development, and the measurement of the functional orientation is a measure of customer orientation. Gebauer (2012) takes the function of the distribution center as the main point of the research, analyzes the distribution center in the actual operation and the operation process of the packaging processing capacity, carrying capacity, sorting and handling capacity, information service and scientific management ability [10]. But they have ignored the needs of customers and how to improve customer service levels. Enterprise accounting can also show the evaluation of enterprise logistics distribution, but it has not formed a comprehensive evaluation of the authority and the standard. According to the meaning and influence factors of customer satisfaction, Sinem (2013) set up the evaluation index system of customer satisfaction in logistics and distribution operations [11]. Sharma (2014) believes that the performance evaluation index of logistics distribution center includes distribution business, order processing, information service and customer service [12]. Ramanathan (2012) believes that the logistics distribution center performance includes: transportation cost, warehouse cost, self team operation cost, customer service and so on. Some scholar set up the logistics distribution center performance evaluation index, the main consideration of the financial indicators: sales net interest rate, sales gross margin, inventory turnover, inventory turnover days and business cycle, total assets turnover, net assets turnover rate. China Federation of logistics and purchasing Federation proposed expert distribution center distribution operation effect evaluation indicators include economic benefits, customer service, picking and shipping, inventory and other.

To sum up the index key lies in the construction of economic indicators, to the exclusion of the customer information, lack of customer satisfaction and effectiveness of feedback measure the performance of the index, is not comprehensive. This makes the establishment of the index system lack of scientific and comprehensive. 


\section{Research Method and Indicator System}

Through the scientific evaluation of $\mathrm{B} 2 \mathrm{C}$ e-commerce logistics service quality, can help enterprises to find out the customer perception of logistics service quality of the reasons, so that enterprises take timely measures to improve the quality of service, improve the competitiveness of $\mathrm{B} 2 \mathrm{C}$ e-commerce enterprises. The premise of scientific evaluation is to establish a sound and complete evaluation index system of service quality. The characteristics of the intangible, production and consumption of logistics services make it difficult for us to evaluate the quantitative evaluation index, and the evaluation of $\mathrm{B} 2 \mathrm{C}$ e-commerce logistics service quality is more focused on customer perceived service quality.

\subsection{Service Quality Evaluation Index Construction}

The evaluation index is a reflection of the key factors that affect the quality of logistics service under the $\mathrm{B} 2 \mathrm{C}$ e-commerce environment. Its reasonable construction is the basis for the evaluation and evaluation of logistics service quality. At the same time, in the selection of evaluation indicators, because of the impact of logistics service quality factors, so in the selection should have a certain standard, and not the better, should choose the key, a representative index, and should be selected from different angles. Therefore, in the construction of B2C ecommerce logistics service quality evaluation index system should follow the following principles:

1) The principle of representative: the selection of indicators for comprehensive evaluation is a more comprehensive evaluation method, the $\mathrm{B} 2 \mathrm{C}$ e-commerce logistics service quality evaluation, as a result of the indicators are more, will be all the indicators are not desirable, should be selected from the impact factors in a representative index, select different angles, different levels of key indicators. In the research of this paper, the evaluation index of logistics service quality not only involves logistics distribution, but also reflects the index of customer marketing and entity distribution. In the selection index, it should have a thorough understanding of the actual meaning of the representative, otherwise it will be easy to confuse the concept in the evaluation, and weaken the effect of the final evaluation.

2) Taking customer as the core criterion: This paper mainly studies the quality of logistics service under the B2C electronic business model. According to the former analysis, the service quality is discussed from the perspective of consumers. Only when consumers perceive the quality of logistics service, the quality of service is good. Therefore, it is necessary to select the core of customer's requirement and perception. This article takes this principle as an important standard to select the index.

3) Overall principle: In the selection of $\mathrm{B} 2 \mathrm{C}$ e-commerce mode of logistics service quality evaluation index, it should be selected to accurately reflect the consumer demand for logistics service factors, select the indicators reflect the quality of logistics service quality in B2C.

4) Operational principle: in the evaluation of logistics service quality, some indicators need to collect data in advance to evaluate, and whether data collection or statistical analysis are required to invest time and cost. If the selection of indicators is difficult to obtain or the cost of obtaining data is too high, it is not reasonable. In addition, the $\mathrm{B} 2 \mathrm{C}$ e-commerce logistics service 
quality evaluation, the selection of indicators should be obtained from the specific practice of logistics enterprises, the acquisition of its data should be feasible and operable.

5) The combination principle of qualitative and quantitative: $\mathrm{B} 2 \mathrm{C}$ e-commerce logistics service quality evaluation index system involves many indicators, which not only involves the logistics distribution of indicators, but also reflects the customer marketing, information service indicators, so the evaluation of its service quality has become complex. The selection of quantitative indicators is scientific and reasonable in the evaluation of service quality, but because of the characteristics of the production and consumption of logistics service, the quantitative index and the evaluation of the quality of logistics service in every aspect, need to be described.

\subsection{Evaluation Index of B2C e-commerce Logistics Service Quality}

In the construction of $\mathrm{B} 2 \mathrm{C}$ e-commerce logistics service quality evaluation index system, should be the first reference to the traditional service quality measurement index. According to the characteristics of $\mathrm{B} 2 \mathrm{C}$ e-commerce logistics service quality indicators, according to the development of their own industry, the impact of factors on the quality of service has changed, as well as the important degree of the indicators have changed. This paper mainly refers to the SERVQUAL and LSQ model in the construction of B2C ecommerce logistics service quality evaluation index, combined with the author's understanding of the content of $\mathrm{B} 2 \mathrm{C}$ e-commerce logistics service quality, from the reliability index, economic index, time index, service flexibility index and information index five aspects to construct index evaluation system.

Reliability is the ability to timely, accurate customer commitment to service, so that customers can rest assured that online shopping. Mainly refers to the $\mathrm{B} 2 \mathrm{C}$ electronic commerce logistics enterprises and their service staff to comply with the commitment to bring customers in advance of the service, including the delivery of goods and equipment is reliable, etc. According to the analysis of $\mathrm{B} 2 \mathrm{C}$ e-commerce logistics service and the classic index system, the author will express the reliability of the indicators are: logistics equipment, goods are intact, the goods are correct. The index directly reflects the quality of the logistics transportation, storage, distribution, packaging, handling and other operations, the higher the value of the index, the higher the logistics service quality of the enterprise. Whether the goods are correct or not, whether the product is delivered to the consumer, whether the product is purchased by the consumer.

The economic index is the price that the customer pays for the logistics service, which is included in all the expenses. In the case of the buyer's market, consumers in the evaluation of logistics prices, more attention to the logistics service that is the price of the product and provides the quality of the logistics is matched. In addition, when the consumer receives the product does not meet the expectations of consumers, businesses to return goods. At this time the transaction has not been completed, the return of the cost will have an impact on the quality of the customer's subjective evaluation. Therefore, this paper will reflect the cost of the indicators is summarized as logistics prices return costs.

Refers to the time index compared with traditional retail, B2C e-commerce is a business and logistics separation transaction. For people who are more and more efficient, the shorter the reaction time, the faster the logistics speed, the higher the degree of satisfaction. From consumer to confirm the order, the order response time, logistics time, error handling should be counted in time into the areas. This paper in reference based on the views of past scholars, the reaction time of the index have been grouped into: order response time, delivery time, returns error processing time three indicators.

Service flexibility index is the improvement of people's living standards; the demand for services is also becoming more diverse. Service flexibility refers to the logistics 
service under the $\mathrm{B} 2 \mathrm{C}$ e-commerce environment, which can provide more and more flexible services according to the different needs of consumers. From the consumer to confirm the order to receive payment for goods, which involves the flexibility of the response of the indicators are: communication skills, flexibility, and attitude.

Information index is that consumers can learn from the network on a timely understanding of the delivery status of goods, goods location and other information. So that consumers can timely understand the product in the process of logistics information. Based on the analysis of the characteristics of logistics services in $\mathrm{B} 2 \mathrm{C}$ e-commerce, this paper concludes that the information of the response is: information timeliness, information accuracy, information adequacy, error information feedback ability. As shown in table 1.

Table 1. B2C e-commerce Logistics Service Quality Evaluation Index

\begin{tabular}{|c|c|c|}
\hline level-1 indexes & level-2 indexes & level-3 indexes \\
\hline \multirow{15}{*}{$\begin{array}{c}\text { E-commerce logistics } \\
\text { service quality } \\
\text { evaluation index }\end{array}$} & \multirow{3}{*}{ Reliability } & Logistics equipment \\
\hline & & Correct goods \\
\hline & & Goods in good condition \\
\hline & \multirow{2}{*}{ Economy } & Logistics price \\
\hline & & Return cost \\
\hline & \multirow{3}{*}{ Time } & Order response time \\
\hline & & Delivery time \\
\hline & & Return response time \\
\hline & \multirow{3}{*}{ Service flexibility } & Flexible way \\
\hline & & Attitude \\
\hline & & Communication skills \\
\hline & \multirow{4}{*}{ Information } & Timely information \\
\hline & & Full information \\
\hline & & Correct information \\
\hline & & Error information feedback \\
\hline
\end{tabular}

\section{Empirical analysis}

\subsection{Fuzzy Comprehensive Evaluation Method}

The object of this paper is Zhengzhou Aviation Logistics Port, through the construction of the logistics service quality evaluation system, the evaluation of the business logistics service quality. In the evaluation, it mainly depends on the subjective judgment of the clients, and has some fuzziness. Customers are very difficult to evaluate through specific data. Therefore, based on the analysis of service quality evaluation method, this paper adopts the method of analytic hierarchy process and fuzzy comprehensive evaluation method to evaluate the quality of $\mathrm{B} 2 \mathrm{C}$ e-commerce logistics service. The fuzzy comprehensive evaluation method firstly judges all kinds of factors affecting the evaluation object, and then uses fuzzy mathematics to evaluate the research object. The first fuzzy set is designed to illustrate the importance of the index, which is expressed as the weight of each index. Second fuzzy sets are designed to show the fuzzy degree of the evaluation grade and the evaluation index, which is the membership function. Finally, according to the study of the need to carry out the two fuzzy sets, the evaluation results can be analyzed. Therefore, the choice of the index weight method and the determination of fuzzy relational matrix are the key points of evaluation. 


\subsection{Index Weight Determination}

In this research, the $\mathrm{B} 2 \mathrm{C}$ e-commerce logistics service quality index weight questionnaire was distributed to the logistics field. Scholars have carried on the two comparison of the relative importance of the index of each layer. In the case of the judgment, the judgment matrix of each level index and two indexes is obtained. Then calculate the weight of each index. Results are shown in table 2, at this time, $\lambda_{\max }=5.2979$, consistency test $\mathrm{CR}=0.0744$, it can through a one-time inspection.

Table 2. Index Judgment Matrix and Weight

\begin{tabular}{|c|c|c|c|c|c|c|}
\hline $\begin{array}{c}\text { First level } \\
\text { indicator }\end{array}$ & Reliability & Time & Economy & Information & $\begin{array}{c}\text { Service } \\
\text { flexibility }\end{array}$ & WI \\
\hline Reliability & 1 & 4 & 1 & 3 & 5 & 0.3756 \\
\hline Time & $1 / 4$ & 1 & $1 / 3$ & $1 / 2$ & $1 / 2$ & 0.0764 \\
\hline Economy & 1 & 3 & 1 & 1 & 3 & 0.2570 \\
\hline Information & $1 / 3$ & 2 & 1 & 1 & 5 & 0.2107 \\
\hline $\begin{array}{c}\text { Service } \\
\text { flexibility }\end{array}$ & $1 / 5$ & 2 & $1 / 3$ & $1 / 5$ & 1 & 0.0802 \\
\hline
\end{tabular}

Table 3. Reliability Index Judgment Matrix and Weight

\begin{tabular}{|c|c|c|c|c|}
\hline Reliability & $\begin{array}{c}\text { Logistics } \\
\text { equipment }\end{array}$ & $\begin{array}{c}\text { Goods in good } \\
\text { condition }\end{array}$ & $\begin{array}{c}\text { Accurate } \\
\text { goods }\end{array}$ & WI \\
\hline Logistics equipment & 1 & $1 / 6$ & $1 / 7$ & 0.0716 \\
\hline $\begin{array}{c}\text { Goods in good } \\
\text { condition }\end{array}$ & 6 & 1 & 1 & 0.4523 \\
\hline Accurate goods & 7 & 1 & 1 & 0.4761 \\
\hline
\end{tabular}

Table 4. Time Index Judgment Matrix and Weight

\begin{tabular}{|c|c|c|c|c|}
\hline Time & Delivery time & $\begin{array}{c}\text { Returns the } \\
\text { response time }\end{array}$ & $\begin{array}{c}\text { Order response } \\
\text { time }\end{array}$ & WI \\
\hline Delivery time & 1 & 5 & 2 & 0.5695 \\
\hline $\begin{array}{c}\text { Returns the } \\
\text { response time }\end{array}$ & $1 / 5$ & 1 & $1 / 4$ & 0.0974 \\
\hline $\begin{array}{c}\text { Order response } \\
\text { time }\end{array}$ & $1 / 2$ & 4 & 1 & 0.3331 \\
\hline
\end{tabular}

Table 5. Economy Index Judgment Matrix and Weight

\begin{tabular}{|c|c|c|c|}
\hline Economy & Logistics price & Return cost & WI \\
\hline Logistics price & 1 & 3 & 0.7500 \\
\hline Return cost & $1 / 3$ & 1 & 0.2500 \\
\hline
\end{tabular}

Table 6. Flexible Service Index Judgment Matrix and Weight

\begin{tabular}{|c|c|c|c|c|}
\hline Flexible service & Flexible way & Staff attitudes & Communication & WI \\
\hline Flexible way & 1 & 5 & $1 / 2$ & 0.1877 \\
\hline Staff attitudes & $1 / 5$ & 1 & $1 / 5$ & 0.0588 \\
\hline Communication & 2 & 5 & 1 & 0.2938 \\
\hline
\end{tabular}

The values of the consistency index CR in the above six tables are less than 0.1. The judgment matrix given by the expert can reflect the objective facts, and it can be 
evaluated comprehensively. The following is the evaluation of $\mathrm{B} 2 \mathrm{C}$ e-commerce logistics service quality of the weight of each indicator.

Table 7. E-commerce Logistics Service Quality Evaluation Index Weight

\begin{tabular}{|c|c|c|c|}
\hline level-1 indexes & level-2 indexes & level-3 indexes & final weight \\
\hline \multirow{15}{*}{$\begin{array}{c}\text { E-commerce } \\
\text { logistics service } \\
\text { quality } \\
\text { evaluation index }\end{array}$} & \multirow{3}{*}{$\begin{array}{l}\text { Reliability } \\
(0.3756)\end{array}$} & Logistics equipment & 0.0269 \\
\hline & & Correct goods & 0.1699 \\
\hline & & Goods in good condition & 0.1789 \\
\hline & \multirow{2}{*}{$\begin{array}{l}\text { Economy } \\
(0.2570)\end{array}$} & Logistics price & 0.1928 \\
\hline & & Return cost & 0.0643 \\
\hline & \multirow{3}{*}{$\begin{array}{c}\text { Time } \\
(0.0764)\end{array}$} & Order response time & 0.0435 \\
\hline & & Delivery time & 0.0074 \\
\hline & & Return response time & 0.0254 \\
\hline & \multirow{3}{*}{$\begin{array}{l}\text { Service flexibility } \\
\quad(0.0802)\end{array}$} & Flexible way & 0.0151 \\
\hline & & Attitude & 0.0047 \\
\hline & & Communication skills & 0.0236 \\
\hline & \multirow{4}{*}{$\begin{array}{l}\text { Information } \\
(0.2107)\end{array}$} & Timely information & 0.1336 \\
\hline & & Full information & 0.0437 \\
\hline & & Correct information & 0.0167 \\
\hline & & $\begin{array}{c}\text { Error information } \\
\text { feedback }\end{array}$ & 0.0152 \\
\hline
\end{tabular}

\subsection{Logistics Service Quality Evaluation and Analysis}

In the fuzzy comprehensive evaluation, the fuzzy relationship matrix of the evaluation grade is needed to be calculated. The evaluation grades are satisfied, satisfied, and general, not satisfied, five grades, according to the above description. In the calculation of the degree of membership of the rating, we have issued a questionnaire to 500 consumers, consumers according to their own service experience for each indicator of the corresponding rate. We are based on the frequency of the indicators in each comment to indicate the degree of the evaluation of the degree of membership. Through the questionnaire of the sort of fuzzy relation matrix for the reliability evaluation of Zhengzhou Airport Logistics:

$$
R_{1}=\left(\begin{array}{lllll}
0.1 & 0.2 & 0.4 & 0.2 & 0.1 \\
0.1 & 0.2 & 0.3 & 0.2 & 0.2 \\
0.2 & 0.3 & 0.3 & 0.1 & 0.1
\end{array}\right)
$$

The fuzzy relation matrix of economic indicators is as follows:

$$
R_{2}=\left(\begin{array}{lllll}
0.2 & 0.3 & 0.3 & 0.1 & 0.1 \\
0.1 & 0.3 & 0.2 & 0.2 & 0.2
\end{array}\right)
$$

The fuzzy relation matrix of timeliness indicators are as follows:

$$
R_{3}=\left(\begin{array}{lllll}
0.2 & 0.2 & 0.3 & 0.2 & 0.1 \\
0.1 & 0.2 & 0.4 & 0.2 & 0.2 \\
0.3 & 0.2 & 0.3 & 0.1 & 0.1
\end{array}\right)
$$

The fuzzy relation matrix of flexible service indicators are as follows:

$$
R_{4}=\left(\begin{array}{lllll}
0.2 & 0.1 & 0.3 & 0.2 & 0.1 \\
0.2 & 0.3 & 0.3 & 0.2 & 0.0 \\
0.2 & 0.2 & 0.3 & 0.2 & 0.1
\end{array}\right)
$$


The fuzzy relational matrix of information index is:

$$
R_{5}=\left(\begin{array}{lllll}
0.1 & 0.3 & 0.3 & 0.2 & 0.1 \\
0.2 & 0.2 & 0.3 & 0.2 & 0.1 \\
0.1 & 0.2 & 0.3 & 0.3 & 0.1 \\
0.1 & 0.2 & 0.3 & 0.2 & 0.2
\end{array}\right)
$$

After calculating the weight of each index and corresponding membership degree, the use of the above mentioned is multiplied by the bounded and operator for the first and two stage fuzzy comprehensive evaluations.

$$
\begin{gathered}
A_{1} \cdot R_{1}=\left[\begin{array}{lllll}
0.1476 & 0.2476 & 0.3072 & 0.1524 & 0.1452
\end{array}\right] \\
A_{2} \cdot R_{2}=\left[\begin{array}{lllll}
0.2260 & 0.2001 & 0.3097 & 0.1670 & 0.10
\end{array}\right] \\
A_{3} \cdot R_{3}=\left[\begin{array}{lllll}
0.1750 & 0.304 & 0 . .275 & 0.125 & 0.125
\end{array}\right] \\
A_{4} \cdot R_{4}=\left[\begin{array}{lllll}
0.1208 & 0.2634 & 0 . .3 & 0.2079 & 0.1079
\end{array}\right] \\
A_{5} \cdot R_{5}=\left[\begin{array}{lllll}
0.203 & 0.1599 & 0.3460 & 0.1540 & 0.1401
\end{array}\right]
\end{gathered}
$$

So that, the performance evaluation of Zhengzhou airport logistics distribution center can be measured, as:

$$
C=\frac{1 \times 0.16+2 \times 0.25^{2}+3 \times 0.3^{2}+4 \times 0.15^{2}+5 \times 0.13^{2}}{0.16^{2}+0.25^{2}+0.3^{2}+0.15^{2}+0.13^{2}}=2.7
$$

\section{Conclusion}

In this paper, we make the performance evaluation of the logistics distribution center of e-commerce enterprises, by combines the characteristics of e-commerce logistics distribution, taking the Zhengzhou Aviation Logistics Port as an example, establishes a set of performance evaluation system suitable for the electronic commerce enterprise distribution center. In this paper, we establish the index system from five aspects: reliability index, economic index, time index, service flexibility index and information index, which have the evaluation of economic benefit and the evaluation of the whole process. Practical applications and e-commerce enterprises should be in the quality of homework, strengthening management, reducing cargo loss and damage of frequency, the establishment of good electronic information platform, logistics and distribution of high efficiency; on staff training, improve staff's basic quality; establish a good feedback mechanism, improve customer satisfaction and service level.

\subsection{Strengthen the Construction of Self-logistics System}

B2C e-commerce enterprise self-built logistics system involves a warehousing, packaging, transportation, and other links, one-time investment, the cost is bigger. But for the operating condition of good, logistics and distribution to achieve the scale effect of B2C e-commerce enterprises, self built logistics has a greater advantage than the cost. First, self built logistics can help enterprises to strengthen control. In the case of self built logistics enterprises can be controlled by the internal system of the self built logistics. At the same time, the supply chain can be controlled in time. Secondly, self built logistics is a part of the whole logistics system, which is closely related with other departments of the enterprise, and can reflect the logistics requirements of customers in a short time. 


\subsection{Promote the Development of the Third-party Logistics}

The third party logistics enterprise, although it can help B2C e-commerce enterprises to focus on the core business, can reduce logistics costs, but the premise is the advantage of the third party logistics enterprise development is good. At present, the development of the third party logistics enterprises in China is not very optimistic. Most of the existing third party logistics enterprises are small, the majority can only provide a single transport, warehousing, distribution services, the third party logistics enterprises have the ability to provide value-added services, the overall service level is low. The management of distribution service staff has a very important influence on the quality of logistics service quality of B2C e-commerce enterprise. For consumers, only under the order and pick up time and logistics enterprises have the most direct contact, so at this time staff service attitude is good or bad for consumers have the most direct impact. In addition, in the empirical research part of this paper, we also see that consumers are not high, so the enterprise must pay attention to the management of logistics and distribution personnel.

\subsection{Strengthen Cooperation between Enterprises}

For B2C e-commerce enterprises, the completion of the transaction needs to be supported by the logistics system. For logistics enterprises, the development of ecommerce has brought a broad space for its growth. Therefore, e-commerce enterprises and logistics enterprises should strengthen cooperation and achieve win-win. The electronic commerce enterprise should first according to the actual need of the business in the choice of the logistics cooperation supplier. For the third party logistics supplier qualification and credit status have a detailed understanding. Secondly, because some business enterprise is the logistics outsourcing to the third party, so the ability of its business control greatly weakened, in order to reduce the risk of e-commerce enterprises can contact more logistics providers, the risk sharing. E-Commerce enterprises should share third party logistics service provider's product distribution information in real time, and have a timely understanding of the service quality feedback. At the same time, the electronic business enterprise should be from the customer to get the logistics service quality report to the logistics cooperation enterprise, so that it can improve. The third party logistics enterprises should have regular communication with the electronic business enterprise, and have a certain understanding of the development of e-commerce enterprises.

\section{Acknowledgements}

The work of this paper is supported by the Key Scientific Research Program Plan of Colleges and Universities in Henan Province: Research on the influencing factors of the aviation logistics industry development in Zhengzhou Experimental zone for comprehensive aviation and economy (Grant No.14B630028)

\section{References}

[1] H. Markus, "Teacher's reflections on experimenting with technology-enriched inquiry-based mathematics teaching with a preplanned teaching unit", The Journal of Mathematical Behavior, vol. 32, no. 3, (2013), pp.295-308.

[2] N.M.Shamsudin, and N.Abdullah, "Strategies of Teaching Science Using an Inquiry based Science Education (IBSE) by Novice Chemistry Teachers”,Procedia - Social and Behavioral Sciences, vol. 90, no.10,(2013), pp.583-592.

[3] S.Gao, and J.Wang, "Teaching transformation under centralized curriculum and teacher learning community: Two Chinese chemistry teachers' experiences in developing inquiry-based instruction”, Teaching and Teacher Education, vol. 44, (2014), pp.1-11.

[4] L.wuesong, and L.qihui, "Inquiry Learning' Implementation and Evaluation in the Teaching of Information Technology”,Physics Procedia, vol. 24, (2012), pp.1851-1856. 
[5] L.Lopes, and T.Bettencourt, "Functional features of group work developed by 12 grade students within “inquiry teaching approach",Procedia - Social and Behavioral Sciences, vol. 15, 2011,pp.3143-3147

[6] P.Lisievici, "An Exploratory Inquiry into the Attractiveness of Teaching Career in Romanian Education System", Procedia - Social and Behavioral Sciences, vol. 78, (2013), pp.260-264 .

[7] M.Vlassi, and A.Karaliota, "The Comparison between Guided Inquiry and Traditional Teaching Method. A Case Study for the Teaching of the Structure of Matter to 8th Grade Greek Students",Procedia - Social and Behavioral Sciences, vol. 93, (2013), pp. 494-497

[8] S.Kroothkaew, and N.Srisawasdi, "Teaching How Light can be Refracted Using Simulation-based Inquiry with a Dual-situated Learning Model”, Procedia - Social and Behavioral Sciences, vol. 93, (2013), pp.2023-2027.

[9] A.K. Kitot, A.R.Ahmad, "The Effectiveness of Inquiry Teaching in Enhancing Students' Critical Thinking",Procedia - Social and Behavioral Sciences, vol. 7, (2010), pp.264-273.

[10] D.R.Garrison, and M.Cleveland-Innes, "Exploring causal relationships among teaching, cognitive and social presence: Student perceptions of the community of inquiry framework", The Internet and Higher Education, vol. 13, No.1,(2010), pp.31-36.

[11] R.Hussain, and A.Bakar, "Eye on teaching: improving practice through research inquiries", Procedia Social and Behavioral Sciences, vol. 9, (2010), pp.403-407.

[12] A.S. Salerno, and A.K. Kibler, "Understanding how pre-service English teachers adopt stance toward academic teaching inquiry tasks",Linguistics and Education, vol. 28,(2014), pp.92-106. 
International Journal of Security and Its Applications

Vol.9, No.10 (2015) 